\title{
Caries-preventive Effect of 1300ppm Fluoride and Carrageenan Containing Toothpaste
}

\author{
Anton Rahardjo ${ }^{1}$, Karina ${ }^{2}$, Adini Fadhilah², Yosi K. Eriwati ${ }^{3}$, Siti Triaminingsih ${ }^{3}$, Diah A. \\ Maharani ${ }^{1}$ \\ ${ }^{1}$ Department of Preventive and Public Health Dentistry, Faculty of Dentistry, Universitas Indonesia, Jakarta \\ 10430, Indonesia \\ ${ }^{2}$ Undergraduate Program, Faculty of Dentistry, Universitas Indonesia, Jakarta 10430, Indonesia \\ ${ }^{3}$ Department of Dental Material, Faculty of Dentistry, Universitas Indonesia, Jakarta 10430, Indonesia \\ Correspondence e-mail to: antonrahardjo@gmail.com
}

\begin{abstract}
Various studies stated that the increase concentration of fluoride in toothpastes leads to the reduction of calcium loss in enamel. Objective: The purpose of this study was to test the difference between the effect of $1300 \mathrm{ppm}$ fluoride with carrageenan toothpaste and 1000ppm fluoride only toothpaste on roughness and hardness of enamel surface. Methods: Enamel specimens were obtained from 30 extracted human premolars. The enamel specimens were randomly assigned to one of the three groups, $1300 \mathrm{ppm}$ fluoride with carrageenan toothpaste, $1000 \mathrm{ppm}$ fluoride only toothpaste and toothpaste with no fluoride as a negative control. The samples were immersed in $1 \%$ citric acid with $\mathrm{pH} 4$ for 150 seconds for demineralization, afterwards exposed to each toothpaste for 6 minutes. Results: The results demonstrated that toothpaste with $1300 \mathrm{ppm}$ fluoride with carregeenan has two times greater efficacy in triggering remineralization than toothpaste with $1000 \mathrm{ppm}$ fluoride only, with regards to surface roughness and hardness recovery in an in vitro caries model. Conclusion: The results suggested that treatment of enamel with toothpaste containing $1300 \mathrm{ppm}$ fluoride with carrageenan has high potential in inducing remineralization on enamel.
\end{abstract}

\begin{abstract}
ABSTRAK
Efek pencegahan karies pasta gigi dengan kandungan $1300 \mathrm{ppm}$ fluoride dan carrageenan. Berbagai studi menyebutkan bahwa peningkatan konsentrasi fluoride dalam pasta gigi dapat mengurangi hilangnya kalsium dalam enamel. Tujuan: Tujuan dari penelitian ini adalah untuk menguji perbedaan antara efek pasta gigi yang mengandung carrageenan dan fluoride 1300ppm dengan pasta gigi yang hanya mengandung fluoride 1000ppm pada permukaan email gigi manusia. Metode: Spesimen email diperoleh dari 30 gigi premolar manusia yang telah diekstraksi. Sampel email dibagi secara acak kepada salah satu dari tiga kelompok, pasta gigi dengan carrageenan berfluoride $1300 \mathrm{ppm}$, pasta gigi berfluoride 1000ppm dan kontrol negatif. Sampel direndam dalam asam sitrat 1\% dengan pH 4 selama 150 detik untuk demineralisasi. Kemudian masing-masing pasta gigi diaplikasikan selama 6 menit. Demineralisasi dinilai dari segi kekasaran dan kekerasan email. Hasil: Pasta gigi dengan carrageenan berfluoride 1300ppm memiliki dua kali lebih besar keberhasilan dalam memicu remineralisasi dibandingkan dengan kelompok 1000ppm. Hal ini berkaitan dengan pemulihan kekasaran dan kekerasan permukaan email gigi dalam model karies in vitro. Simpulan: Pasta gigi dengan carrageenan berfluoride 1300ppm mempunyai potensi yang tinggi dalam menginduksi remineralisasi pada email gigi.
\end{abstract}

Key words: carrageenan, enamel, fluoride, hardness, roughness, toothpaste

\section{INTRODUCTION}

Fluoride has been a vital agent in caries prevention since the last century. The caries preventive effect of fluoride is mainly attributed to its effects on demineralization and remineralization process of dental hard tissue at the tooth-oral fluids interface. ${ }^{1}$
The substitution of hydroxyl ions by fluoride ions in the mineral crystal, forms fluoroapatite which is more resistant to acid attack than hydoxyapatite. Therefore, the loss of mineral is prevented before it can be detected microscopically. $1-5$ 
Fluoride plays an important role in preventing dental caries, not only by reducing the caries progression rate, but also by inducing the arrest of active lesions. In other words, fluoride has combination of two modes, inhibition of demineralization and stimulation of remineralization. Topically applied fluoride in different concentrations has the capability of reducing dental caries development in vitro and in vivo. Various clinical studies have shown that introduction of fluoride shifts the balance from demineralization to remineralization. The rapid progression of dental caries may be prevented by high fluoride concentrated toothpaste, which can prevent calcium loss in the enamel..$^{1-5}$ Dental caries occurrence is strongly associated with dynamic process of demineralization and remineralization in the enamel surface. Moreover, the loss and addition of minerals that occurs during the process of demineralization and remineralization affect the roughness and hardness of enamel.

After demineralization, enamel roughness increase and enamel hardness decrease. On the contrary, remineralization causes increased enamel hardness and decreased enamel roughness. Therefore, enamel surface roughness and hardness are considered as determinants describing the effects of remineralization and demineralization process on enamel surfaces. Over the counter toothpaste usually content $1000 \mathrm{ppm}$ fluoride. This study is important because only few studies had been conducted to test the efficacy of $1300 \mathrm{ppm}$ fluoride and additional carregeenan in toothpaste. ${ }^{6-10}$ In an effort to prevent dental caries, the efficacy of a toothpaste containing carrageenan with $1300 \mathrm{ppm}$ fluoride was compared to that of $1000 \mathrm{ppm}$ fluoride with carrageenan. An intra-oral experimental caries model was employed, to evaluate the anti-caries effect of the high fluoride concentration toothpaste.

\section{METHODS}

This was an in vitro experimental study. The specimens were 30 freshly extracted human premolars that were done for orthodontic treatment. All teeth were examined visually to ensure there were no micro cracks and surface defects. Teeth then were embedded in acrylic mold and randomly divided into three groups (Table 1). Baseline data (B) were collected for each sample before any intervention. Then the samples were immersed in $1 \%$ citric acid with $\mathrm{pH}$ 4 for 150 seconds for demineralization. Data after demineralization (D) were obtained. Further, the samples were exposed to the toothpastes tested for 6 minutes. Remineralization ( $\mathrm{R}$ ) was assessed in terms of enamel hardness and roughness. Enamel surface roughness measurement were made using Mitutoyo SJ 301 surface roughness tester. Knoop test was employed for enamel surface hardness analysis. ${ }^{11-15}$

Moreover, data were analyzed using SPSS and mean differences between groups were analyzed using ANOVA test with significance level of 0.05 . Mean values and standard deviations were calculated for the different variables.

\section{RESULTS}

The roughness values for enamel groups were described in Table 2. After demineralization with $1 \%$ citric acid, the G2 group samples (1000ppm fluoride toothpaste), the enamel roughness recovery was $2.02 \%$ higher than placebo, while the G3 (toothpaste with 1300ppm fluoride and carrageenan) recovered $4.20 \%$ higher compared to placebo. The results demonstrated that G3 toothpaste showed two times greater remineralization potential than G2 toothpaste. The microhardness values for enamel groups were shown in Table 3. Remineralization intervention after demineralization with $1 \%$ citric acid, enamel roughness recovery of G2 group after was $87.7 \%$, while that of G3 group recovered the enamel hardness $168.9 \%$, almost two times than G2. These results showed that toothpaste with $1300 \mathrm{ppm}$ fluoride has two times greater efficacy than that of $1000 \mathrm{ppm}$ fluoride, with regards to surface hardness recovery and fluoride uptake in an in vitro caries model.

\section{DISCUSSION}

Fluoride toothpastes have been used extensively and their anti-cariogenic properties have been evaluated through laboratory, clinical and epidemiological studies. The aim of the present in vitro study was to compare the effect of toothpaste with carrageenan containing fluoride $1300 \mathrm{ppm}$ with that of $1000 \mathrm{ppm}$. The best way to simulate the in vivo environment is through the use of in vitro cycling demineralization/remineralization model, which is equivalent to the dynamics of tooth decay development. In order to get valid results, the in vitro studies should use methodologies that simulate what happens in the mouth as well as techniques with results presenting correlation with in vivo studies. The present study used a $\mathrm{pH}$ cycling model, which simulates the cariogenic process. The 150 seconds acid exposure was aimed to imitate real situation when patient consumes sugar-containing products and fails to remove dental plaque. The 6 minutes soaks of toothpaste treatment simulate the retention period of fluoride in the mouth and the remineralization solution mimics the saliva repair period. Therefore, the results of this study may have some correlation with the clinical situation. ${ }^{16-20}$ The purpose of microhardness analysis was testing its correlation with remineralization process. Microhardness testing was used to evaluate the resistance against demineralization considering that there is a good correlation between enamel microhardness and mineral loss in carious lesion. At lower $\mathrm{pH}$ more enamel are dissolved during demineralization phase, providing additional reactive sites (porosities); and decay process causes reduction in the crystals' size. 
Table 1. Toothpastes used in the study

\begin{tabular}{|c|c|c|}
\hline Group & Tothpaste & Active Ingredients \\
\hline G1 & $\begin{array}{l}\text { Control } \\
\text { (no carrageenan \& } \\
\text { fluoride) }\end{array}$ & $\begin{array}{l}\text { Calcium Carbonate, Sorbitol, Water, Silica, Propylene Glycol, PEG-8, } \\
\text { Sodium Lauryl Sulfate, Flavour, Xanthan Gum, Glycerin, Sodium Saccharin, Methylparaben, } \\
\text { Ethylparaben, Butylparaben, o-Cymen-5-ol (IPMP), Xylitol, Tocopheryl Acetate (Vit E } \\
\text { Acetate), Retinyl Palmitate (Vit A Palmitate), Sodium Ascorbyl Phosphate (Vit C) }\end{array}$ \\
\hline G2 & $\begin{array}{l}\text { Ciptadent } \\
\text { (with carrageenan } \\
\& 1000 \text { ppm fluoride) }\end{array}$ & $\begin{array}{l}\text { Calcium Carbonate, Sorbitol, Water, Silica, Propylene Glycol, PEG- } 8 \text {, } \\
\text { Sodium Lauryl Sulfate, Flavour, Sodium Monofluorophosphate } 0.76 \% \text {, Xanthan Gum, } \\
\text { Carrageenan, Glycerin, Sodium Saccharin, Methylparaben, Ethylparaben, Butylparaben, } \\
\text { o-Cymen-5-ol (IPMP), Xylitol, Sodium Fluoride } 0.01 \% \text {, Tocopheryl Acetate (Vit E Acetate), } \\
\text { Retinyl Palmitate (Vit A Palmitate), Sodium Ascorbyl Phosphate (Vit C) }\end{array}$ \\
\hline G3 & $\begin{array}{l}\text { Ciptadent } \\
\text { (with carrageenan } \\
\& 1300 \mathrm{ppm} \\
\text { fluoride) }\end{array}$ & $\begin{array}{l}\text { Calcium Carbonate, Sorbitol, Water, Silica, Propylene Glycol, PEG- } 8 \text {, } \\
\text { Sodium Lauryl Sulfate, Flavour, Sodium Monofluorophosphate } 0.76 \% \text {, Xanthan Gum, } \\
\text { Carrageenan, Glycerin, Sodium Saccharin, Methylparaben, Ethylparaben, Butylparaben, } \\
\text { o-Cymen-5-ol (IPMP), Xylitol, Sodium Fluoride } 0.06 \% \text {, Tocopheryl Acetate (Vit E Acetate), } \\
\text { Retinyl Palmitate (Vit A Palmitate), Sodium Ascorbyl Phosphate (VitC) }\end{array}$ \\
\hline
\end{tabular}

Table 2. Enamel surface roughness parameter mean \pm standard error

\begin{tabular}{lcccccc}
\hline Toothpaste & $\mathbf{B}$ & $\mathbf{D}$ & $\mathbf{R}$ & $\mathbf{d R}$ & $\mathbf{d D}$ & $\%$ \\
\hline $\mathrm{G} 1(\mathrm{~N}=10)$ & $0.0337 \pm 0.0074$ & $0.0360 \pm 0.0077$ & $0.0850 \pm 0.0207$ & $0.0023 \pm 0.0001$ & $0.0490 \pm 0.0050$ & - \\
$\mathrm{G} 2(\mathrm{~N}=10)$ & $0.0353 \pm 0.0005$ & $0.0403 \pm 0.0006$ & $0.0663 \pm 0.0017$ & $0.0050 \pm 0.0003$ & $0.0260 \pm 0.0008$ & 2.02 \\
$\mathrm{G} 3(\mathrm{~N}=10)$ & $0.0353 \pm 0.0004$ & $0.0447 \pm 0.0004$ & $0.0570 \pm 0.0003$ & $0.0093 \pm 0.0005$ & $0.0123 \pm 0.0001$ & 4.20 \\
$p$ & $\mathrm{NS}$ & $* *$ & $* *$ & $*$ & $* * *$ & \\
\hline
\end{tabular}

baseline (B), after demineralization (D), after remineralization (R), changes after remineralization (dR), changes after demineralization (dD) and percentage changes comparing to placebo/G1 (\%); NS (not significant), $*: p<0.05,{ }^{* *}: p<0.01,{ }^{* * *}$ : $p<0.001$

Table 3. Enamel surface hardness parameter mean \pm standard error

\begin{tabular}{lcccccc}
\hline Toothpaste & $\mathbf{B}$ & $\mathbf{D}$ & $\mathbf{R}$ & $\mathbf{d R}$ & $\mathbf{d D}$ & $\mathbf{\%}$ \\
\hline $\mathrm{G} 1(\mathrm{~N}=10)$ & $348 \pm 21.971$ & $297 \pm 8.343$ & $310 \pm 6.663$ & $51 \pm 24.042$ & $14 \pm 6.237$ & 29.8 \\
$\mathrm{G} 2(\mathrm{~N}=10)$ & $355 \pm 20.277$ & $296 \pm 22.012$ & $346 \pm 13.985$ & $59 \pm 22.446$ & $50 \pm 17.008$ & 87.7 \\
$\mathrm{G} 3(\mathrm{~N}=10)$ & $346 \pm 24.598$ & $303 \pm 13.189$ & $362 \pm 13.256$ & $43 \pm 19.771$ & $59 \pm 19.103$ & 168.9 \\
$p$ & $\mathrm{NS}$ & $\mathrm{NS}$ & $* * *$ & $\mathrm{NS}$ & $* * *$ & \\
\hline
\end{tabular}

baseline (B), after deminerarilzation (D), after remineraliztion (R), changes after remineraliztion (dR), changes after deminerarilzation $(\mathrm{dD})$ and percentage enamel hardness recovery (remineralization) after demineralization (\%); NS (not significant), $*: p<0.05, * *: p<0.01, * * *: p<0.001$

The enamel surface hardness and roughness analysis demonstrated higher resistance to demineralization of toothpaste containing $1300 \mathrm{ppm}$ than the $1000 \mathrm{ppm}$ toothpaste and placebo. Moreover, carrageenan might increase the efficacy of the toothpaste. Carrageenan which is polysaccharides extracted from red seaweed, stabilizes the toothpaste. Carrageenan is the only agent capable to stabilize toothpaste without modifying the system texture due to its high specificity. Specific interaction between carrageenan and the surface of abrasive disperses and stabilizes the solids, preventing hardening, caking and drying out. Other binders that are now available in the market have one or some of the properties of carrageenan, however they do not the same combination as carrageenan. This makes carrageenan is unique in the dentifrice industry. ${ }^{20-23}$

\section{CONCLUSION}

This in vitro study demonstrated that the use of a toothpaste with carrageenan and $1300 \mathrm{ppm}$ fluoride was able to sustain enamel roughness and hardness two times better than that of $1000 \mathrm{ppm}$. These showed that 
toothpaste with carrageenan and $1300 \mathrm{ppm}$ fluoride has a potential cariostatic effect.

\section{ACKNOWLEDGEMENT}

The support of Lion Wings for this research was greatly appreciated.

\section{REFERENCES}

1. Featherstone JD. Fluoride, remineralization and root caries. Am J Dent. 1994;7:271-4.

2. Mukai Y, Lagerweij MD, ten Cate JM. Effect of a solution with high fluoride concentration on remineralization of shallow and deep root surface caries in vitro. Caries Res. 2001;35:317-24.

3. Nyvad B, ten Cate JM, Fejerskov O. Arrest of root surface caries in situ. J Dent Res. 1997;76:1845-53.

4. Baysan A, Lynch E, Ellwood R, Davies R, Petersson L, Borsboom P. Reversal of primary root caries using dentifrices containing 5,000 and 1,100 ppm fluoride. Caries Res. 2001;35:41-6.

5. Ganss C, Klimek J, Starck C. Quantitative analysis of the impact of the organic matrix on the fluoride effect on erosion progression in human dentine using longitudinal micro radiography. Arch Oral Biol. 2004;49:931-5.

6. Lo EC, Schwarz E, Wong MC. Arresting dentine caries in Chinese preschool children. Int J Paediatr Dent. 1998;8:253-60.

7. Warrick JM, Miller LL, Doan EJ, Stookey GK. Caries-preventive effects of sodium and amine fluoride dentifrices. Am J Dent. 1999;12:9-13.

8. Manning RH, Edgar WM. Intra- oral models for studying de- and remineralization in man. methodology and measurement. J Dent Res. 1992; 71:895-900.

9. Wang CW, Corpron RE, Lamb WJ, Strachan DS, Kowalski CJ. In situ remineralization of enamel lesions using continuous versus intermittent fluoride application. Caries Res. 1993;27:455-60.

10. Kielbassa AM, Shohadai SP, Schulte-Monting J. Effect of saliva substitutes on mineral content of demineralized and sound dental enamel. Support Care Cancer. 2001;9:40-7.

11. Zero DT. In situ caries models. Adv Dent Res.1995;9:214-30.

12. Wefel JS. Effects of fluoride on caries development and progression using intra-oral models. J Dent Res. 1990;69:626-33.
13. Banoczy J, Szoke J, Kertesz P, Toth Z, Zimmermann $P$, Gintner Z. Effect of amine fluoride/stannous fluoride-containing toothpaste and mouthrinsings on dental plaque, gingivitis, plaque and enamel F-accumulation. Caries Res.1989;23:284-8.

14. Ogaard B, Alm AA, Larsson E, Adolfsson U. A prospective, randomized clinical study on the effects of an amine fluoride/ stannous fluoride toothpaste/mouthrinse on plaque, gingivitis and initial caries lesion development in orthodontic patients. Eur J Orthod. 2006;28:8-12.

15. Paraskevas S, Danser MM, Timmerman MF, Velden U van der, Weijden GA van der. Amine fluoride/stannous fluoride and incidence of root caries in periodontal maintenance patients. A 2 year evaluation. J Clin Periodontol. 2004;31:96571.

16. Lynch E, Baysan A, Ellwood R, Davies R, Petersson L, Borsboom P. Effectiveness of two fluoride dentifrices to arrest root carious lesions. Am J Dent. 2000;13:218-20.

17. Khamverdi Z, Kasraie S, Rezaei-Soufi L, Jebeli S. Comparison of the effects of two whitening toothpastes on microhardness of the enamel and a microhybride composite resin: an in vitro study. J Dent. 2010;7:139-45.

18. Bizhang M, Chun YP, Winterfeld M, Altenburger MJ, Raab WHM, Zimmer S. Effect of a 5000 ppm fluoride toothpaste and a $250 \mathrm{ppm}$ fluoride mouth rinse on the demineralisation of dentin surfaces. BMC Res Notes. 2009;2:147.

19. Delbem ACB, Brighenti FL, Vieira A, Cury JA. In vitro comparison of the cariostatic effect between topical application of fluoride gels and fluoride toothpaste. J Appl Oral Sci. 2004;12:121-6.

20. Queiroz CS, Hara AT, Leme AFP, Cury JA. $\mathrm{pH}$-cycling models to evaluate the effect of low fluoride dentifrice on enamel and remineralization. Braz Dent J.2008;19:21-7.

21. Hilgenberg SP, Pinto SCS, Farago PV, Santos VA, Wambier DS. Physical-chemical characteristics of whitening toothpaste and evaluation of its effects on enamel roughness. Braz Oral Res. 2011;25:28894.

22. Iglauer S, Wu Yongfu, Shuler P, Tang Y, Goddard AW. Dilute iota- and kappa-carrageenan solutions with high viscosities in high. J Petroleum Sci Eng. 2011;75:304-11.

23. Kadajji VG, Betageri GV. Water soluble polymers for pharmaceutical applications. Polymers. 2011;3:1972-2009. 